\title{
Control of Postharvest Decay in Pear by Four Laboratory-Grown Yeasts and Two Registered Biocontrol Products
}

\author{
David Sugar, Oregon State University, Southern Oregon Research and Extension Center, 569 Hanley Rd., Medford \\ 97502, and Robert A. Spotts, Oregon State University, Mid-Columbia Agricultural Research and Extension Center, \\ Hood River 97031
}

\begin{abstract}
Sugar, D., and Spotts, R. A. 1999. Control of postharvest decay in pear by four laboratorygrown yeasts and two registered biocontrol products. Plant Dis. 83:155-158.

Control of blue mold decay in Bosc pears was studied with the laboratory-grown yeasts Rhodotorula glutinis, Cryptococcus infirmo-miniatus, and two strains of Cryptococcus laurentii, as well as registered biocontrol products Aspire, containing the yeast Candida oleophila, and BioSave 11 (now Bio-Save 110), containing the bacterium Pseudomonas syringae. Both thiabendazole (TBZ)-sensitive and TBZ-resistant strains of Penicillium expansum were used. Aspire treatment reduced the average lesion diameter by approximately 65 and $45 \%$, and reduced decay incidence by 27 and $9 \%$ with TBZ-resistant and TBZ-sensitive P. expansum, respectively, in the first year of the study, but did not result in significant decay control in the second year. Bio-Save 11 reduced decay lesion diameter by 32 to $72 \%$ and incidence by 21 to $40 \%$ over the 2 years. In both years, TBZ-sensitive $P$. expansum was completely controlled by the combination of either C. laurentii (both strains), R. glutinis, or C. infirmo-miniatus with $100 \mathrm{ppm}$ TBZ. With TBZresistant $P$. expansum, control of wound infection with these yeasts alone or with $100 \mathrm{ppm}$ TBZ ranged from 62.9 to $100 \%$. In a packinghouse trial, control by Bio-Save $110+100 \mathrm{ppm}$ TBZ and Aspire $+100 \mathrm{ppm} \mathrm{TBZ}$ was not different than control by TBZ at $569 \mathrm{ppm}$, the maximum label rate. The amount of decay following Aspire $+100 \mathrm{ppm}$ TBZ treatment was significantly less than the amount of decay following Bio-Save $110+100$ ppm TBZ treatment.
\end{abstract}

Additional keywords: biological control, Pyrus communis

Postharvest fungal decay of pear (Pyrus communis L.) fruit causes substantial economic loss for the fruit industry of the $\mathrm{Pa}-$ cific Northwest (8). Pears destined for long-term storage are generally treated with the fungicide thiabendazole (TBZ) to control susceptible postharvest pathogens (8). However, TBZ does not control all postharvest pathogen species capable of infecting pear (15), and resistant strains of otherwise benzimidazole-sensitive species are encountered in commercial pear packinghouses (12). Furthermore, some export markets have low or no tolerance for TBZ residues on fruit (15). Thus, there have been several investigations of biological or cultural methods to potentially enhance or replace TBZ as a postharvest treatment for pears $(1-3,5-7,10,14)$.

Two biological control products, Aspire (Ecogen, Langhorne, PA), which contains the yeast Candida oleophila strain I-182 (4), and Bio-Save 110 (EcoScience, Worcester, MA; formerly Bio-Save 11), which contains a saprophytic strain of the

Corresponding author: David Sugar

E-mail: David.Sugar@orst.edu

Accepted for publication 3 November 1998.

Publication no. D-1998-1207-01R

(C) 1999 The American Phytopathological Society bacterium Pseudomonas syringae (5), are currently registered for postharvest application to pears. Several other potential biocontrol agents have been isolated from fruit surfaces and shown to suppress postharvest decay in pear $(1-3,11)$.

This study compared the effects of four yeasts isolated in the Pacific Northwest and the registered biocontrol products in controlling both a TBZ-sensitive and a TBZ-resistant strain of Penicillium expansum Link, causal agent of blue mold of pear. In addition, a packinghouse trial was conducted in which Aspire and Bio-Save 110 , each combined with a reduced dosage of TBZ, were each compared with TBZ at the full label rate and with an untreated control.

\section{MATERIALS AND METHODS}

Biological control agents. The Cryptococcus laurentii strain 87-108, originally isolated from the surface of an apple in Wenatchee, WA, was provided for this study by R. G. Roberts (11). The C. laurentii strain HRA5, the Rhodotorula glutinis strain HRB6, and the $C$. infirmominiatus strain YY6 were originally isolated by Chand-Goyal and Spotts from the surfaces of pear fruit from Hood River, OR (C. laurentii and $R$. glutinis), or Yakima, WA (C. infirmo-miniatus) (1).

The above yeasts were maintained at $-20^{\circ} \mathrm{C}$ on yeast malt dextrose broth
(YMDB: $3 \mathrm{~g}$ of malt extract, $3 \mathrm{~g}$ of yeast extract, $5 \mathrm{~g}$ of peptone, and $10 \mathrm{~g}$ of dextrose per liter of medium) until use. The yeasts were activated by dispensing $1 \mathrm{ml}$ of thawed suspension into $75 \mathrm{ml}$ of sterile YMDB in a $250-\mathrm{ml}$ flask. After 2 days of incubation at $20^{\circ} \mathrm{C}$ on a shaker, $0.1-\mathrm{ml}$ aliquots of yeast suspension were placed on petri dishes containing yeast malt dextrose agar (YMDA: YMDB plus $18 \mathrm{~g}$ of agar per liter). After 2 days of incubation at $20^{\circ} \mathrm{C}$, yeast colonies were removed by scraping the dishes with a sterile rubber spatula and the yeasts were suspended in sterile, distilled water. Suspensions of $C$. laurentii 87-108 were adjusted to $2 \%$ transmittance at $595 \mathrm{~nm}$ with a Spectronic 20 spectrophotometer to give a concentration of 2.8 to $3.3 \times 10^{8} \mathrm{CFU}$ per ml. Suspensions of $C$. laurentii HRA5, $R$. glutinis, and $C$. infirmo-miniatus were adjusted to $2 \%$ transmittance at $550 \mathrm{~nm}$ to give a concentration of 1.0 to $1.5 \times 10^{8} \mathrm{CFU}$ per ml. Spectrophotometric determinations of yeast concentrations were confirmed by dilution plating of the treatment suspensions.

The formulated biological control products Aspire and Bio-Save 11 were obtained from commercial distributors. Aspire was maintained at $4^{\circ} \mathrm{C}$, and Bio-Save 11 at $-70^{\circ} \mathrm{C}$. The products were used at maximum label rates of $3.0 \mathrm{~g} / \mathrm{liter}$ and $1.7 \mathrm{~g} /$ liter, respectively.

Pathogen inoculum. The TBZ-resistant isolate of $P$. expansum (strain MR1) used in these experiments was originally isolated from a blue mold lesion on pear in Medford, OR. The TBZ-sensitive isolate of $P$. expansum (strain HR46) was originally isolated from a blue mold lesion on pear in Hood River, OR. Inoculum was prepared by washing conidia from the surfaces of 2 to 4-week-old colonies of each strain growing on potato dextrose agar (PDA; Difco, Detroit, MI) with sterile, distilled water, then adjusting the final concentration of conidia in suspension to approximately $1 \times 10^{4}$ conidia per $\mathrm{ml}$ with the aid of a hemacytometer. The TBZ sensitivity of each isolate was confirmed prior to the experiment by placing filter paper disks soaked in a 569-ppm TBZ solution onto PDA plates that had been spread with 0.5 $\mathrm{ml}$ of a solution containing approximately $1 \times 10^{4}$ conidia per ml. A clear zone of inhibition appeared around the disks on plates of the sensitive isolate, while none developed on plates of the resistant isolate. 
Fruit. Bosc pears were harvested at mid-range maturity (approximately $65 \mathrm{~N}$ firmness as measured by a Magness-Taylor penetrometer with a 8-mm tip) from trees at the Southern Oregon Research and Extension Center in Medford. Two hundred fruit were harvested from each of five trees, and maintained in separate cartons as replicates. Harvested fruit were immediately stored in air at $0^{\circ} \mathrm{C}$ until use.

Treatments. Prior to inoculation, each fruit was surface disinfested for $5 \mathrm{~min}$ in a $0.5 \% \mathrm{NaOCl}$ solution. Fruit were then rinsed in fresh water and placed on fiberboard fruit trays on a laminar-flow sterile bench. Fruit surfaces were lightly sprayed with $70 \%$ ethanol and allowed to dry. Each fruit was then wounded in five locations with the head of a sterile steel finishing nail. The resulting wounds were approximately $3 \mathrm{~mm}$ deep and $6 \mathrm{~mm}$ in diameter, simulating wounds created when pear flesh is punctured by the stem of another pear.

Biocontrol treatments consisted of the following: $C$. laurentii HRA5, R. glutinis HRB6, C. infirmo-miniatus YY6, C. laurentii 87-108, Aspire, Aspire $+2 \% \mathrm{CaCl}_{2}$, and Bio-Save 11, and each of the above biocontrol agents combined with $100 \mathrm{ppm}$ TBZ. Additional treatments were $100 \mathrm{ppm}$ TBZ, 569 ppm (wt/wt) TBZ (full label rate of Mertect 340F; Novartis, Basel), and sterile, distilled water as a control.

For each treatment, 20 fruit $(100$ wounds) were inoculated by placing $40 \mu \mathrm{l}$ of one of the above treatments into each wound by micropipette. Each wound subsequently received $40 \mu \mathrm{l}$ of TBZ-sensitive $P$. expansum spore suspension. Each treatment was done five times. The sequence was then repeated with inoculum of TBZresistant $P$. expansum.
Trays of inoculated fruit were wrapped in perforated polyethylene bags and placed into fiberboard cartons. Cartons were stored in conventional air storage at $0^{\circ} \mathrm{C}$. After 2 months of storage, lesions developing about wounds were measured with Vernier calipers across the lesion diameter perpendicular to the stem-calyx axis of the fruit, and visibly infected lesions were counted. The experiment was first conducted in 1995 and repeated in 1996.

Packinghouse trial. In 1996, a commercial packinghouse in Medford, OR, cooperated in a test of decay control in Bosc pears with Bio-Save 110 combined with $100 \mathrm{ppm}$ TBZ, Aspire combined with $100 \mathrm{ppm}$ TBZ, or the standard treatment of TBZ at 569 ppm (as Mertect 340F). Pears from a single large orchard were packed over a 2-day period. Each morning and in the afternoon of the first day, the tank used as a reservoir of fungicide solution and all hoses, belts, and brushes in the treatment area were rinsed thoroughly with water. The tank was then charged with one of the treatments as a 3,785-liter suspension and applied to fruit as a line spray. Approximately $8.3 \mathrm{ml}$ of treatment suspension was applied per $\mathrm{kg}$ of fruit. Over the course of each of the three morning or afternoon treatment periods, 10 packed boxes (net weight approximately $20 \mathrm{~kg} ; 120$ fruit per box) were collected at random time intervals from the end of the packing line. Ten boxes were filled from field bins (one box per bin) prior to entering the packinghouse dump tanks to serve as untreated controls. All boxes of fruit were transported to the Southern Oregon Research and Extension Center for storage in air at $0^{\circ} \mathrm{C}$. Four and 6 months after treatment (6 and 8 months after harvest), decayed fruit were removed from boxes and the type and quantity of decay visually identified.

Statistical analyses. Data for disease severity (lesion diameters) and incidence (percent wounds infected) were analyzed by analysis of variance (ANOVA) with CoStat Statistical Software (CoHort Software, Berkeley, CA), and means were separated by Fisher' protected least significant difference test. Percentages of wounds infected were transformed by arc sine (square root) prior to analysis.

\section{RESULTS}

Laboratory study. In the control treatment, blue mold lesions developed at 98.4 to $99.2 \%$ of the inoculated wounds, and average lesion diameters were between 21.2 and $23.4 \mathrm{~mm}$, regardless of the TBZ sensitivity of the inoculum (Table 1). Aspire treatment reduced the average lesion diameter by approximately 65 and $45 \%$, and reduced decay incidence by 27 and $9 \%$ with TBZ-resistant and TBZ-sensitive $P$. expansum, respectively, in 1995, but did not reduce decay severity significantly in 1996. Addition of $2 \% \mathrm{CaCl}_{2}$ to Aspire reduced incidence and severity of decay caused by TBZ-sensitive $P$. expansum in 1995, but did not improve control in 1996. In 1995, Bio-Save 11 treatment reduced the average lesion diameter by approximately 72 and $71 \%$, and reduced decay incidence by 31 and $48 \%$ with TBZ-resistant and TBZ-sensitive $P$. expansum, respectively. In 1996, Bio-Save 11 reduced the average lesion diameter by approximately 53 and $32 \%$, and reduced decay incidence by 40 and $21 \%$ with TBZ-resistant and TBZsensitive $P$. expansum, respectively.

In general, treatment with laboratorygrown yeasts alone resulted in greater control of decay than did treatment with

Table 1. Effects of biological and chemical treatments on blue mold lesion development at artificial wounds in Bosc pear fruit

\begin{tabular}{|c|c|c|c|c|c|c|c|c|}
\hline \multirow[b]{3}{*}{ Treatment } & \multicolumn{4}{|c|}{1995} & \multicolumn{4}{|c|}{1996} \\
\hline & \multicolumn{2}{|c|}{ Lesion diameter (mm) } & \multicolumn{2}{|c|}{ Wounds infected (\%) } & \multicolumn{2}{|c|}{ Lesion diameter (mm) } & \multicolumn{2}{|c|}{ Wounds infected (\%) } \\
\hline & TBZ-Sw & TBZ-R $^{\mathbf{w}}$ & TBZ-S & TBZ-R & TBZ-S & TBZ-R & TBZ-S & TBZ-R \\
\hline Cryptococcus laurentii HRA5 ${ }^{\mathrm{x}}$ & $1.9 \mathrm{~b}^{\mathrm{y}}$ & $2.2 \mathrm{a}$ & $18.4 \mathrm{~cd}$ & $18.0 \mathrm{ab}$ & $4.9 \mathrm{c}$ & $3.2 \mathrm{ab}$ & $35.2 \mathrm{e}$ & $32.4 \mathrm{c}$ \\
\hline Rhodotorula glutinis $\mathrm{HRB}^{\mathrm{x}}$ & $1.2 \mathrm{ab}$ & $1.1 \mathrm{a}$ & $12.4 \mathrm{bc}$ & $12.4 \mathrm{ab}$ & $3.5 \mathrm{bc}$ & $2.9 \mathrm{ab}$ & $33.6 \mathrm{e}$ & $29.2 \mathrm{c}$ \\
\hline C. infirmo-miniatus $\mathrm{YY}^{\mathrm{x}}$ & $1.8 \mathrm{~b}$ & $0.7 \mathrm{a}$ & $20.8 \mathrm{~d}$ & $9.6 \mathrm{ab}$ & $3.7 \mathrm{c}$ & $1.2 \mathrm{ab}$ & $28.8 \mathrm{e}$ & $11.2 \mathrm{~b}$ \\
\hline C. laurentii $87-108^{\mathrm{z}}$ & $0.2 \mathrm{a}$ & $0.7 \mathrm{a}$ & $2.0 \mathrm{a}$ & $6.0 \mathrm{a}$ & $0.6 \mathrm{a}$ & $3.7 \mathrm{ab}$ & $5.6 \mathrm{~cd}$ & $27.6 \mathrm{c}$ \\
\hline Aspire & $12.9 \mathrm{e}$ & $7.2 \mathrm{~b}$ & $89.2 \mathrm{~g}$ & $72.0 \mathrm{~d}$ & $23.4 \mathrm{e}$ & 21.0 ef & $97.2 \mathrm{~g}$ & $100.0 \mathrm{~h}$ \\
\hline Aspire $+2 \% \mathrm{CaCl}_{2}$ & $9.9 \mathrm{~d}$ & $8.5 \mathrm{bc}$ & $78.0 \mathrm{f}$ & $80.4 \mathrm{de}$ & $22.7 \mathrm{e}$ & $14.8 \mathrm{~cd}$ & $98.4 \mathrm{~g}$ & $92.8 \mathrm{efg}$ \\
\hline Bio-Save 11 & $6.5 \mathrm{c}$ & $6.1 \mathrm{~b}$ & $68.0 \mathrm{e}$ & $51.6 \mathrm{c}$ & $10.9 \mathrm{~d}$ & $13.1 \mathrm{~cd}$ & $67.2 \mathrm{f}$ & $78.4 \mathrm{~d}$ \\
\hline C. laurentii HRA5 + TBZ 100 ppm & $0.0 \mathrm{a}$ & $2.0 \mathrm{a}$ & $0.0 \mathrm{a}$ & $20.4 \mathrm{ab}$ & $0.0 \mathrm{a}$ & $5.2 \mathrm{~b}$ & $0.0 \mathrm{a}$ & $36.4 \mathrm{c}$ \\
\hline R. glutinis HRB6 + TBZ 100 ppm & $0.0 \mathrm{a}$ & $1.9 \mathrm{a}$ & $0.0 \mathrm{a}$ & $21.2 \mathrm{~b}$ & $0.0 \mathrm{a}$ & $2.4 \mathrm{ab}$ & $0.0 \mathrm{a}$ & $20.4 \mathrm{bc}$ \\
\hline C. infirmo-miniatus YY6 + TBZ $100 \mathrm{ppm}$ & $0.0 \mathrm{a}$ & $0.9 \mathrm{a}$ & $0.0 \mathrm{a}$ & $10.8 \mathrm{ab}$ & $0.0 \mathrm{a}$ & $5.6 \mathrm{~b}$ & $0.0 \mathrm{a}$ & $20.8 \mathrm{bc}$ \\
\hline C. laurentii 87-108 + TBZ 100 ppm & $0.0 \mathrm{a}$ & $0.8 \mathrm{a}$ & $0.0 \mathrm{a}$ & $9.6 \mathrm{ab}$ & $0.0 \mathrm{a}$ & $0.0 \mathrm{a}$ & $0.0 \mathrm{a}$ & $0.0 \mathrm{a}$ \\
\hline Aspire + TBZ 100 ppm & $0.0 \mathrm{a}$ & $10.6 \mathrm{c}$ & $0.0 \mathrm{a}$ & 92.8 ef & $0.8 \mathrm{a}$ & $23.2 \mathrm{f}$ & $9.2 \mathrm{~cd}$ & $97.6 \mathrm{gh}$ \\
\hline Aspire $+2 \% \mathrm{CaCl}_{2}+\mathrm{TBZ} 100 \mathrm{ppm}$ & $0.0 \mathrm{a}$ & $7.9 \mathrm{bc}$ & $0.0 \mathrm{a}$ & $78.4 \mathrm{~d}$ & $0.3 \mathrm{a}$ & $17.4 \mathrm{de}$ & $4.0 \mathrm{bc}$ & $95.6 \mathrm{fgh}$ \\
\hline Bio-Save 11 + TBZ 100 ppm & $0.3 \mathrm{a}$ & $16.0 \mathrm{~d}$ & $4.0 \mathrm{a}$ & $77.2 \mathrm{de}$ & $0.0 \mathrm{a}$ & $14.2 \mathrm{~cd}$ & $0.0 \mathrm{a}$ & $86.0 \mathrm{de}$ \\
\hline TBZ 100 ppm & $0.8 \mathrm{ab}$ & $19.7 \mathrm{e}$ & $8.4 \mathrm{ab}$ & $95.2 \mathrm{f}$ & $1.5 \mathrm{ab}$ & $12.8 \mathrm{c}$ & $17.2 \mathrm{~d}$ & $80.0 \mathrm{e}$ \\
\hline TBZ 569 ppm & $0.2 \mathrm{a}$ & $15.6 \mathrm{~d}$ & $2.8 \mathrm{a}$ & $92.4 \mathrm{ef}$ & $1.3 \mathrm{a}$ & $13.8 \mathrm{~cd}$ & $14.4 \mathrm{~cd}$ & 88.0 def \\
\hline Control & $23.4 \mathrm{f}$ & $21.2 \mathrm{e}$ & $98.4 \mathrm{~h}$ & $98.8 \mathrm{f}$ & $23.4 \mathrm{e}$ & $21.9 \mathrm{f}$ & $99.2 \mathrm{~g}$ & $98.8 \mathrm{~h}$ \\
\hline
\end{tabular}

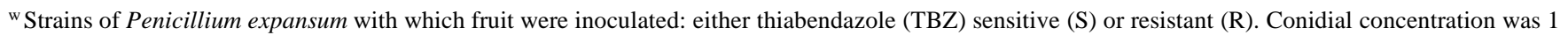
$\times 10^{4}$ per ml.

x Treatment suspension contained 1.0 to $1.5 \times 10^{8} \mathrm{CFU}$ per $\mathrm{ml}$.

y Values within a column followed by the same letter are not significantly different according to Fisher's protected least significant difference $(P>0.05)$.

z Treatment suspension contained 2.8 to $3.3 \times 10^{8} \mathrm{CFU}$ per ml. 
either of the registered biocontrol products (Table 1). In both years, the combination of either $C$. laurentii (both strains), $R$. glutinis, or C. infirmo-miniatus with $100 \mathrm{ppm}$ TBZ gave complete control of TBZsensitive $P$. expansum. With TBZ-resistant $P$. expansum, control of wound infection with these yeasts alone or with $100 \mathrm{ppm}$ TBZ ranged from 62.9 to $100 \%$. The TBZ sensitivity of the $P$. expansum isolate used did not consistently influence the ability of the biocontrol agents to control lesion development.

TBZ alone at either 100 or 569 ppm reduced blue mold lesion development with TBZ-resistant $P$. expansum in 1996 but not in 1995. In 1996, TBZ at 100 and 569 ppm reduced blue mold incidence at wounds by 19.0 and $10.9 \%$, respectively, compared with the control treatment.

Packinghouse trial. Blue mold was the most common type of decay found in the packinghouse trial (Table 2). The total of all types of decay was $17 \%$ of fruit in the untreated control, and treatments reduced decay incidence by 59 to $85 \%$. All treatments reduced decay significantly $(P<$ 0.05), compared with the control. Control by Bio-Save $110+100$ ppm TBZ and Aspire +100 ppm TBZ was not different from control by the full rate of TBZ, but the amount of total decay following Aspire +100 ppm TBZ treatment was significantly less than the amount of total decay following Bio-Save $110+100$ ppm TBZ treatment (Table 2).

\section{DISCUSSION}

The yeast-containing biocontrol product Aspire gave inconsistent control of blue mold in the 2 years of our laboratory study. The product was not tested for viability of the active ingredient, and it is possible that handling conditions during shipment could have affected the product efficacy. The Candida oleophila strain I-182 has been reported to provide significant control of $P$. expansum infection of nectarines (9), and $P$. expansum and $P$. digitatum infection of apples and citrus fruits, respectively (4). On apples and citrus, control was improved by combination with $10 \%$ of the label rate of TBZ (4). In our packinghouse trial, Aspire combined with $100 \mathrm{ppm}$ TBZ was as effective as TBZ alone at the maximum label rate $(569 \mathrm{ppm})$ in controlling decay (Table 2).

Table 2. Cumulative decay in Bosc pears 8 months after harvest (6 months after treatment) following line-spray applications in a commercial packinghouse

\begin{tabular}{lccccc}
\hline Treatment & $\begin{array}{c}\text { Blue } \\
\text { moldy }\end{array}$ & $\begin{array}{c}\text { Gray } \\
\text { mold }\end{array}$ & $\begin{array}{c}\text { Bull's } \\
\text { eye rot }\end{array}$ & $\begin{array}{c}\text { Side and } \\
\text { other rots }\end{array}$ & $\begin{array}{c}\text { Total } \\
\text { decay }\end{array}$ \\
\hline TBZ $^{2}$ (Mertect 340F) $569 \mathrm{ppm}$ & $2.3 \mathrm{a}$ & $0.1 \mathrm{a}$ & $0.0 \mathrm{a}$ & $1.5 \mathrm{~b}$ & $3.9 \mathrm{~b}$ \\
Bio-Save 110 + TBZ 100 ppm & $3.5 \mathrm{a}$ & $0.6 \mathrm{a}$ & $0.4 \mathrm{a}$ & $2.6 \mathrm{bc}$ & $7.0 \mathrm{bc}$ \\
Aspire + TBZ 100 ppm & $2.2 \mathrm{a}$ & $0.2 \mathrm{a}$ & $0.0 \mathrm{a}$ & $0.2 \mathrm{a}$ & $2.6 \mathrm{a}$ \\
Untreated Control & $8.9 \mathrm{~b}$ & $2.1 \mathrm{~b}$ & $0.6 \mathrm{a}$ & $5.4 \mathrm{c}$ & $17.0 \mathrm{c}$ \\
\hline
\end{tabular}

${ }^{y}$ Values within a column followed by the same letter are not significantly different according to Fisher's protected least significant difference $(P>0.05)$.

${ }^{z}$ Thiabendazole.
Jeffers and Hankinson (7) reported that Bio-Save 11 was as good as or better than TBZ in controlling postharvest pear decay in several trials. In our laboratory study, control by Bio-Save 11 was significant in both years, though the level of control was not as great as that of TBZ when tested against TBZ-sensitive $P$. expansum. In our packinghouse trial, Bio-Save 110 combined with $100 \mathrm{ppm}$ TBZ was as effective as TBZ at 569 ppm in controlling decay (Table 2).

Chand-Goyal and Spotts (3) found that control of a TBZ-resistant isolate of $P$. expansum by $C$. laurentii HRA5 was improved by combination with TBZ. They also found that control by $R$. glutinis HRB6 was diminished by combination with 285 ppm TBZ. In the present study, control of $P$. expansum by $R$. glutinis HRB6 was not diminished by 100 ppm TBZ, indicating that this yeast strain may only be sensitive to TBZ at higher concentrations. Recently, the efficacy of C. laurentii HRA5, $R$. glutinis HRB6, and $C$. infirmo-miniatus YY6 was significantly improved when cells were washed to remove residual nutrients carried from the culture medium (R. Spotts, unpublished). This effect is in agreement with the mode of action, which appears to be competition with the pathogen for nutrients at the wound site (2).

The concentrations of laboratory-grown yeasts used in this study were chosen based on published reports of biocontrol efficacy (1-3,11). In semi-commercial and commercial trials, Chand-Goyal and Spotts (3) confirmed that concentrations of $C$. laurentii HRA5, $R$. glutinis HRB6, and $C$. infirmo-miniatus YY6 equal to those used in the present study can be effective in controlling blue mold of pear. Accordingly, we compared registered biocontrol products applied at the maximum label rates and biocontrol agents potentially available in the near future at concentrations likely to be used commercially.

The four laboratory-grown yeasts tested in this study demonstrated excellent potential as biocontrol agents for blue mold of pear. However, it is important that evaluation of these species in a product formulation be carried out to more accurately predict their performance in commercial use. Formulation may improve or diminish efficacy. Stockwell et al. (13) found that ly- ophilized inocula of Erwinia amylovora and of two bacterial antagonists of $E$. amylovora were more effective in colonizing pear flowers than bacteria harvested from actively growing cultures.

Commercial development of $C$. laurentii HRA5, R. glutinis HRB6, and C. infirmominiatus YY6 as biocontrol agents is in progress (3), and testing of formulated products will reveal whether or not these species represent significant improvements over available biocontrol agents for postharvest decay control in pear. It is likely that progress in development and implementation of biocontrol for postharvest decay will involve continued efforts to optimize species selection and application technology.

\section{ACKNOWLEDGMENTS}

We are grateful to K. A. Powers, S. A. Basile, and J. M. Benbow for technical assistance. Oregon Agricultural Experiment Station technical paper 11,441 .

\section{LITERATURE CITED}

1. Chand-Goyal, T., and Spotts, R. A. 1996. Enumeration of bacterial and yeast colonists of apple fruits and identification of epiphytic yeasts on pear fruits in the Pacific Northwest United States. Microbiol. Res. 151:427-432.

2. Chand-Goyal, T., and Spotts, R. A. 1996. Control of postharvest pear diseases using natural saprophytic yeast colonists and their combination with a low dosage of thiabendazole. Postharvest Biol. Biotechnol. 7:51-64.

3. Chand-Goyal, T., and Spotts, R. A. 1997. Biological control of postharvest diseases of apple and pear under semi-commercial and commercial conditions using three saprophytic yeasts. Biol. Control 10:199-206.

4. Hofstein, R., Fridlender, B., Chalutz, E., and Droby, S. 1994. Large-scale production and pilot testing of biological control agents for postharvest diseases. Pages 89-100 in: Biological Control of Postharvest Diseases Theory and Practice. C. L. Wilson, and M. E. Wisniewski, eds. CRC Press, Boca Raton, FL.

5. Janisiewicz, W. J., and Marchi, A. 1992. Control of storage rots on various pear cultivars with a saprophytic strain of Pseudomonas syringae. Plant Dis. 76:555-560.

6. Janisiewicz, W. J., and Roitman, J. 1988. Biological control of blue mold and gray mold on apple and pear with Pseudomonas cepacia. Phytopathology 78:1697-1700.

7. Jeffers, S. N., and Hankinson, T. R. 1995. Biological control of postharvest diseases of apples and pears: Preliminary results from the 1994 Bio-Save field trial program. Proc. Annu. Wash. Tree Fruit Postharvest Conf., 11th, Wenatchee.

8. Kupferman, E. A. 1998. Postharvest chemicals applied to pears: A survey of pear packers in Washington, Oregon, and California. Tree Fruit Postharvest J. 9:3-24.

9. Lurie, S., Droby, S., Chalupowicz, L., and Chalutz, E. 1995. Efficacy of Candida oleophila strain 182 in preventing Penicillium expansum infection of nectarine fruits. Phytoparasitica 23:231-234.

10. Mao, G. H., and Cappellini, R. A. 1989. Postharvest control of gray mold of pear by Pseudomonas gladioli. Phytopathology 79:1153.

11. Roberts, R. G. 1990. Postharvest biological control of gray mold of apple by Cryptococcus laurentii. Phytopathology 80:526-530.

12. Spotts, R. A., and Cervantes, L. A. 1986. Populations, pathogenicity, and benomyl resistance of Botrytis spp., Penicillium spp., and 
Mucor piriformis in packinghouses. Plant Dis. 70:106-108

13. Stockwell, V. O., Johnson, K. B., and Loper, J. E. 1998. Establishment of bacterial antagonists of Erwinia amylovora on pear and apple blossoms as influenced by inoculum prepara- tion. Phytopathology 88:506-513.

14. Sugar, D., Roberts, R. G., Hilton, R. J., Righetti, T. L., and Sanchez, E. E. 1994. Integration of cultural methods with yeast treatment for control of postharvest fruit decay in pear. Plant Dis. 78:791-795.
15. Willett, M. J., Kupferman, E. A., Roberts, R. G., Spotts, R. A., Sugar, D., Apel, G., and Ewart, H. W. 1992. Integrated management of postharvest diseases and disorders of apples, pears, and cherries. Tree Fruit Postharvest J. $3: 3-16$ 